\title{
MEKANISME CORPORATE GOVERNANCE \\ DAN MANAJEMEN LABA MODEL LONG TERM \\ DISCRETIONARY ACCRUAL PADA PERUSAHAAN GO \\ PUBLIK DI INDONESIA
}

\author{
Wiyadi $^{1)}$, Rina Trisnawati ${ }^{2)}$, Ecclisia Sulistyowati $^{3)}$ \\ Sekolah Pascasarjana, Universitas Muhammadiyah Surakarta \\ wiyadi@ums.ac.id
}

\begin{abstract}
Abstrak
Penelitian ini bertujuan menganalisis pengaruh mekanisme corporate governance internal dan eksternal terhadap manajemen laba dengan pendekatan long term discretionary accrual perusahaan go publik di Indonesia yang tergabung dalam indeks LQ45 dan JII selama periode 2011-2015. Sampel penelitian berjumlah 226 perusahaan diambil secara purposive sampling. Mekanisme Corporate Governance terbagi menjadi: Mekanisme Corporate Governance internal dan eksternal. Mekanisme Corporate Governance internal diproksikan dengan komite audit dan dewan komisaris independen. Sedangkan corporate governance eksternal diproksikan dengan konsentrasi kepemilikan dan investor institusi. Metode analisis data menggunakan regresi linier berganda. Hasil penelitian menunjukkan bahwa konsentrasi kepemilikan berpengaruh terhadap manajemen laba. Sedangkan komite audit, dewan komisaris independen dan investor institusi tidak berpengaruh terhadap manajemen laba.
\end{abstract}

Kata Kunci: komite audit, dewan komisaris indepeden, konsentrasi kepemilikan investor institusi.

\begin{abstract}
This study aims to analyze the influence of internal and external corporate governance mechanisms on earnings management with the long term discretionary accrual approach of companies incorporated in the LQ45 and JII indices during the period 2011-2015. The research sample was 226 companies taken by purposive sampling. The Corporate Governance mechanism is divided into: Internal and external Corporate Governance Mechanisms. The internal Corporate Governance mechanism is proxied by the audit committee and independent board of commissioners. While external corporate governance is proxied by the concentration of ownership and institutional investors. Methods of data analysis using multiple linear regression. The results showed that ownership concentration had an effect on earnings management. While the audit committee, independent board of commissioners and institutional investors have no effect on earnings management
\end{abstract}

Keywords: audit committee, independent board of commissioners, concentration of ownership, institutional investors.

\section{Latar Belakang Masalah}

Manajemen laba adalah upaya manajer untuk mempengaruhi informasi dalam laporan keuangan dengan tujuan mengelabuhi pemangku kepentingan yang ingin mengetahui kinerja dan kondisi perusahaan (Sulistyanto, 2008 dalam Wiyadi, 2017:2). Manajemen laba juga diartikan sebagai cara manajer mempengaruhi angka laba dengan sengaja dan sistematis melalui pememilihan 
kebijakan dan prosedur akuntansi tertentu dari standar akuntansi yang ada dengan tujuan memaksimalkan utilitas mereka dan nilai pasar perusahaan (Scott, 2006).

Manajemen laba diukur dengan beberapa model, yaitu: model manajemen laba akrual, model manajemen laba riil, dan manajemen laba terintegrasi. Model manajemen laba akrual terbagi menjadi dua, yaitu: model long term dan model short term. Pada model short term, manajer cenderung menggunakan akun yang mempengaruhi modal kerja dan mencerminkan perubahan pada aktiva lancar dan kewajiban lancar. Sedangkan pada model long term, manajer cenderung menggunakan akun aktiva tetap dan hutang jangka panjang (Kusuma, 2006). Penggunaan akun aktiva tetap berkait dengan penggunaan akun penyusutan, pajak periode mendatang, revaluasi asset, dan penyusutan nilai wajar informasi perusahaan (Whelan, 2004). Pertimbangan penggunaan model long - term karena tindakan manajemen laba tidak dapat dideteksi untuk beberapa periode akuntansi berikutnya (Whelan dan McNamara 2004).

Perspektif manajemen laba terbagi menjadi dua, yaitu: perspektif oportunistik (negatif) dan perspektif efisien (positif). Perilaku oportunistik manajer dapat direduksi melalui mekanisme tata kelola perusahaan atau corporate governance mechanism (Kusuma dan Indra, 2012). Mekanisme corporate governance terbagi menjadi dua, yaitu: mekanisme eksternal dan internal (Qeisari dan Mohammad, 2016).

Mekanisme internal menggambarkan serangkaian hubungan antara manajemen, dewan direksi, pemegang saham dan pemangku kepentingan lainnya dari perusahaan. Mekanisme internal berasal dari ukuran dewan komisaris, proporsi dewan komisaris independen, kepemilikan manajerial, kepemilikan keluarga, konsentrasi kepemilikan, dan komite audit. Sedangkan Mekanisme eksternal menggambarkan sistem yang dimiliki oleh pemangku kepentingan eksternal yang mengarah pada pemisahan kepemilikan dengan manajemen.
Mekanisme eksternal berasal akuntan publik (kualitas audit), investor, kreditor, keputusan pengadilan, dan kepemilikan isntitusional. Tujuan penulisan artikel ini adalah menguji peran mekanisme corporate governance internal dan eksternal terhadap manajemen laba pada perusahaan go public di Indonesia yang tergabung dalam indeks LQ-45 dan JII.

\section{Review Literatur Dan Pengembangan Hipotesis}

Menurut teori agensi, praktik manajemen laba berawal dari adanya konflik kepentingan antara manajer dengan pemilik perusahaan. Dalam arti sempit, manajemen laba adalah perilaku manajer untuk bermain dengan komponen discretionary accruals dalam menentukan besarnya laba. Sedangkan dalam arti luas manajemen laba adalah tindakan manajer untuk menaikkan atau mengurangi angka laba yang dilaporkan tanpa mengakibatkan peningkatan atau penurunan profitabilitas ekonomi jangka panjang sebuah unit usaha.

Praktik manajemen laba dapat diminimumkan melalui penerapan corporate governance, yaitu sebuah mekanisme monitoring yang bertujuan untuk menyelaraskan berbagai kepentingan tersebut (Ujiyantho dan Pramuka, 2007). Menurut Iqbal dan Fachriyah (2008) manajemen laba dapat dieliminasi dengan pengawasan sendiri melalui mekanisme corporate governance.

Mekanisme corporate governance diarahkan untuk menjamin dan mengawasi berjalannya sistem tata kelola dalam sebuah perusahaan dengan tujuan meminimalkan konflik yang terjadi antara agent dan principal. Unsur mekanisme corporate governance yang digunakan dalam penelitian ini antara lain: kepemilikan saham oleh investor institusional (Machfoedz dan Midiastuty, 2003; Ujiyantho dan Pramuka, 2007), kepemilikan saham oleh manajemen (Iqbal dan Fachriyah, 2008; Ujiyantho dan Pramuka, 2007), peran monitoring oleh dewan komisaris (Dechow et.al., 1996 dalam Siregar dan Utama, 2005; Ujiyantho dan Pramuka, 2007), keberadaan 
komite audit (Wedari, 2004), proporsi dewan komisaris independen (Ujiyantho dan Pramuka, 2007; Wedari, 2004).

\section{Komite Audit dan Manajemen Laba}

Komite audit merupakan komponen penting dalam mekanisme corporate governance. Keberadaan komite audit terkait dengan masalah pelaporan keuangan (Hermawan, 2011).Komite auditadalahkomite yang dibentuk oleh dewan komisaris untuk melakukan tugas pengawasan manajemen perusahaan. Komite audit dianggap sebagai penghubung antara pemegang saham dan dewan komisaris dengan manajer dalam menangani masalah pengendalian. Komite audit bertanggung jawab untuk mengawasi laporan keuangan, mengawasi audit internal dan audit eksternal (Meiryani, 2015).

Komite audit berperan memastikan kualitas pelaporan keuangan, dan memberikan kontribusi untuk meminimalkan manipulasi pendapatan (Miko dan Hasnah, 2015). Jadi tujuan pembentukan komite audit untuk meningkatkan akuntabilitas dan transparansi perusahaan kepada para pemangku kepentingan melalui pemberian informasi keuangan yang lebih relevan dan handal. Oleh sebab itu, peran komite audit di perusahaan harus berdampak positif terhadap kualitas informasi laporan keuangan (Hermawan, 2011).

Beberapa peneliti sebelumnya, seperti: Meiryani (2015); Xie, Wallace dan Peter (2003), Rahman dan Fairuzana (2006), Wedari (2004) melakukan penelitian yang hasilnya menyatakan bahwa komite audit berpengaruh negatif terhadap manajemen laba. Dari penjelasan diatas dapat disimpulkan bahwa keberadaan komite audit mampu mengurangi tindakan manajemen laba.

$\mathrm{H}_{1}$ : Komite audit berpengaruh negatif terhadap manajemen laba

\section{Proporsi Dewan Komisaris Independen dan Manajemen Laba}

Dewan komisaris independen adalah pihak yang memiliki peran penting dalam penyediaan laporan keuangan yang reliable. Keberadaan dewan komisaris independen memiliki pengaruh terhadap kualitas laporan keuangan dan digunakan sebagai ukuran tingkat rekayasa keuangan oleh seorang manajer. Dewan komisaris independen mewakili pemegang saham untuk memastikan bahwa seluruh tindakan manajer adalah untuk kepentingan terbaik perusahaan. Dewan komisaris independen harus memiliki pengetahuan dan pengalaman yang memadai dalam bisnis dan memiliki kemampuan untuk memahami laporan keuangan (Hermawan, 2011).

Peran dewan komisaris independen terfokus pada fungsi monitoring pelaksanaan kebijakan manajer agar dapat meminimalkan permasalahan keagenan yang timbul antara direksi dengan pemegang saham (Rachman, 2014). Keberadaan dewan komisaris independen diharapkan dapat meminimalisir praktik manajemen laba karena dewan komisaris independen berfungsi sebagai pemisah kepentingan antara pemegang saham dengan manajer.

Dewan komisaris independen memiliki fungsi kontrol terhadap kinerja manajer dalam mengurus operasional perusahaan (Wardhani, 2007). Melalui pengawasan yang dilakukan oleh dewan komisaris independen diharapkan dapat meminimalkan konflik keagenan antara investor dan manajer. Fungsi dewan komisaris, antara lain; melakukan pengawasan terhadap direksi dalam pencapaian tujuan perusahaan dan memberhentikan direksi untuk sementara bila diperlukan. Dewan komisaris independen secara umum memiliki kontrol yang lebih baik terhadap manajer, sehingga mempengaruhi kecurangan dalam penyajian laporan keuangan. Dewan komisaris dapat melakukan tugasnya sendiri maupun dengan mendelegasikan kewenangannya pada komite yang bertanggung jawab pada dewan komisaris.

Penelitian mengenai pengaruh proporsi dewan komisaris independen terhadap manajemen laba telah dilakukan oleh beberapa peneliti sebelumnya, antara lain: Nasution dan Setiawan (2007), Xie et.al. (2003), Ujiyantho 
dan Pramuka (2007), Wedari (2004), Pratana dan Mas'ud (2003), Klein (2002), Peasnell et.al. (2001), Chtourou et.al. (2001), dan Dechow et.al. (1996). Dari hasilnya dapat disimpulkan bahwa proporsi dewan komisaris independen mampu mengurangi praktik manajemen laba. Berdasarkan penjelasan diatas, maka dapat dirumuskan hipotesis sebagai berikut.

$\mathrm{H}_{2}$ : Proporsi dewan komisaris independen berpengaruh negatif terhadap manajemen laba.

\section{Konsentrasi Kepemilikan Manajemen Laba}

Konsentrasi kepemilikan merupakan sebuah fenomena yang biasa ditemukan di negara dengan ekonomi sedang bertumbuh seperti Indonesia dan di negara-negara continental Europe (Nuryaman, 2009). Konsentrasi kepemilikan mencerminkan pemegang saham yang akan melakukan pengawasan terhadap manajer, namun bila biaya pengawasan tersebut tinggi maka pemegang saham akan menggunakan pihak ketiga (debtholders atau bondholders) untuk membantu melakukan pengawasan.

Menurut Roodposhti dan Chasmi (2011) bahwa konsentrasi kepemilikan adalah sebuah ukuran dari keberadaan pemegang saham yang besar dalam suatu perusahaan. Pemegang saham yang besar memiliki insentif yang lebih besar untuk memantau kinerja manajemen, sebab biaya pemantauan manajemen lebih kecil daripada ekspektasi keuntungan kepemilikan mereka di perusahaan. Pemegang saham yang mampu melakukan pengawasan yang handal adalah pemegang saham atau institusional mayoritas (terkonsentrasi). Alasannya pemilik institusional sebagai pemegang saham mayoritas memiliki kelebihan dibanding investor individual.

Dari sisi pendanaan, pemilik institusional lebih kuat dibanding pemilik individual. Secara umum pemegang saham mayoritas menyerahkan pengelolaan investasinya pada divisi khusus yang memiliki profesionalitas dibidang analisis data keuangan. Sehingga pemilik mayoritas dapat memonitor perkembangan investasinya secara baik. Namun jika persentase kepemilikan mayoritas semakin besar, maka mereka memiliki insentif untuk melakukan pengawasan secara efektif terhadap manajer dan memiliki kemampuan untuk mempengaruhi atau mengubah tindakan keputusan manajer.

Hasil penelitian Alves (2012) dan Gulzar dan Wang (2011) menyatakan bahwa konsentrasi kepemilikan berpengaruh positif terhadap manajemen laba. Namun menurut penelitian Kamran dan Attaullah (2014) dan Nuryaman (2009) bahwa konsentrasi kepemilikan berpengaruh negative terhadap manajemen laba. Dari uraian ini, maka dapat dirumuskan hipotesis sebagai berikut:

$\mathrm{H}_{3}$ : Konsentrasi kepemilikan berpengaruh negatif terhadap manajemen laba.

\section{Investor Institusional dan Manajemen Laba}

Menurut Jalil dan Rashidch (2010) investor institusional berpotensi mempengaruhi praktik manajemen baik secara langsung (melalui kepemilikan) dan tidak langsung (melalui perdagangan saham). Investor institusional merupakan pihak yang memonitor dan mengendalikan manajer. Menurut Ujiyantho dan Pramuka (2007) investor institusional memiliki kemampuan untuk mengendalikan manajer melalui proses monitoring secara efektif, sehingga dapat mengurangi praktik manajemen laba. Semakin banyak investor institusional, maka semakin efektif untuk mempengaruhi maupun mengubah tindakan serta keputusan manajemen (Tarjo, 2008). Berarti dengan adanya penerapan mekanisme corporate governance dalam sistem pengendalian dan pengelolaan perusahaan diharapkan dapat mengurangi tindakan manajemen laba.

Hasil penelitian Kamran dan Attaullah (2014); dan Jalil (2010) menyatakan bawa investor institusi berpengaruh positif terhadap manajen laba. Namun hasil penelitian Hsu dan 
Shiow (2015), dan Machfoedz dan Midiastuty (2003) menunjukkan bahwa investor institusional berpengaruh negatif terhadap manajemen laba. Dari penjelasan diatas, maka dapat dirumuskan hipotesis sebagai berikut:

$\mathrm{H}_{4}$ : Investor institusi berpengaruh negatif terhadap manajemen laba.

\section{Metode Penelitian}

\section{Populasi dan Sampel}

Jenis penelitian ini merupakan penelitian eksplanatori yang digunakan untuk menganalisis pengaruh corporate governance internal dan eksternal terhadap manajemen laba dengan pendekatan short term accrual model pada perusahaan go public yang tergabung dalam LQ45 dan JII Bursa Efek Indonesia selama kurun waktu 2011 - 2015. Sumber data berasal dari laporan keuangan tahunan perusahaan yang dipublikasikan oleh Pusat Refrensi Pasar Modal (PRPM) dan dari Indonesian Capital Market Directionary (ICMD) yang terdapat di Bursa Efek Indonesia melalui www.idx.co.id.

Populasi dalam penelitian ini adalah seluruh perusahaan Go Public yang tergabung dalam LQ45 dan JII selama kurun waktu 2011 - 2015. Sampel penelitian sebanyak 226 perusahaan yang diambil secara purposive sampling dengan kriteria:
a. Perusahaan Go Public yang tergabung dalam LQ45 dan JII BEI yang menyediakan laporan keuangan per 31 desember secara berturut-turur selama kurun waktu 5 tahun periode $2011-2015$.
b. Perusahaan menyajikan laporan keuangan secara lengkap terkait dengan variabel yang diteliti.

\section{Definisi Operasional Pengukuran Variabel}

Variabel dalam penelitian ada tiga, yaitu: variabel dependen, variabel independen, dan variabel kontrol. Menurut Nisfiannoor (2009) variabel dependen (Y) adalah variabel yang dipengaruhi atau yang menjadi akibat variabel independen. Variabel independen (X) adalah variabel yang menjadi sebab perubahan atau munculnya variabel dependen. Dan variabel kontrol adalah kelompok indeks.

Variabel dependen dalam penelitian ini yaitu manajemen laba dengan model long term. Sedangkan variabel variabel independen terdiri dari: komite audit, proporsi dewan komisaris independen, konsentrasi kepemilikan, dan investor institusional. Dan variabel kontrolnya adalah indeks kelompok perusahaan.

Variabel independen:

a. Komite Audit

Komite audit adalah komite yang dibentuk oleh dewan komisaris untuk melakukan tugas pengawasan manajemen perusahaan. Komite audit merupakan penghubung antara pemegang saham dan dewan komisaris dengan manajer dalam menangani masalah pengendalian. Komite audit bertanggung jawab dalam mengawasi laporan keuangan, audit eksternal dan audit internal sehingga mampu mengurangi praktik manajemen laba (Meiryani, 2015). Variabel ini diukur dengan menggunakan jumlah komite audit.

b. Proporsi Dewan Komisaris Independen

Variabel ini berfungsi untuk memastikan transparansi, struktur yang sehat, dan pengambilan keputusan yang rasional. Proporsi dewan komisaris independen adalah proporsi anggota dewan komisaris yang memiliki posisi terbaik untuk melaksanakan penengamatan agar dapat tercipta tata kelola perusahaan yang baik. Indikator yang digunakan untuk mengukur proporsi dewan komisaris independen ini adalah presentase jumlah anggota dewan komisaris yang berasal dari luar perusahaan dari seluruh dewan komisaris. 
$D K I=\frac{J u m l a h \text { dewan komisaris independen }}{\text { Total dewan komisaris yang dimiliki perusahaan }} \times 100 \%$

c. Konsentrasi Kepemilikan

Konsentrasi kepemilikan merupakan kepemilikan saham oleh pemegang saham terbesar atau kepemilikan saham oleh institutional. Variabel konsentrasi kepemilikan di ukur dengan presentase saham yang dimiliki oleh pemegang saham (institusi atau individu) terbesar yang dimiliki oleh pemegang saham institutional (Juliardi, 2013). Konsentrasi kepemilikan diukur dengan menggunakan persentase kepemilikan institusi atau individu yang menunjukan kepemilikan terhadap suatu perusahaan, yaitu dengan menggunakan konsep kepemilikan imediat. Tingkat voting rights (hak kontrol) menggambarkan hak suara yang dikendalikan oleh pemegang saham perusahaan.

d. Investor Institusional Investor institusional memiliki kemampuan mengendalikan pihak manajemen melalui proses monitoting secara efektif sehingga dapatmengurangipraktikmanajemen laba. Investor Institusional diukur dengan menggunakan prosentase kepemilikan institusioanl dengan jumlah modal saham yang beredar.

$$
\text { Investor institusi }=\frac{\text { Jumlah saham yang dimiliki investor institusi }}{\text { Jumlah modal saham yang beredar }}
$$

\section{Variabel Dependen}

Manajemen laba adalah tindakan seorang manajer dengan menaikkan atau menurunkan angka laba yang dilaporkan dari sebuah unit bisnis yang menjadi tanggung jawabnya yang tidak memiliki kaitan dengan kenaikan atau penurunan profitabilitas perusahaan dalam jangka panjang. Pengukuran manajemen laba dengan menggunakan pendekatan long term discretionary accrual.Long term discretionary accrual yaitu terdiri dari penyusutan, pajak periode mendatang, revaluasi asset, dan penyusutan nilai wajar informasi perusahaan.

\section{Manajemen laba dengan pendekatan Long term}

$$
\text { LTDAMi, }=\frac{\text { LTACCi,t }}{\text { TAi, }-1}-\beta 1\left\{\left(\frac{1}{\text { Long TAi, }-1}\right)+\beta 2\left(\frac{P P E i, t}{T A i, t-1}\right)+\beta 3\left(\frac{\text { INTi,t }}{\text { TAi,t }-1}\right)+\beta 4\left(\frac{\text { INCi,t }}{\text { TAi,t }-1}\right)\right.
$$

Keterangan:

LTDAM $_{i, t}$ : Long term discretionary accrual

LTACC $_{i . t}$ : Long term accrual perusahaan i pada tahun $\mathrm{t}$

$\mathrm{TA}_{\mathrm{i}, \mathrm{t}-1} \quad$ : Total Aktiva perusahaan i pada $\mathrm{INC}_{\mathrm{i}, \mathrm{t}}$ tahun $\mathrm{t}-1$

$\log \mathrm{TA}_{\mathrm{i}, \mathrm{t}-1}$ : Logaritma dari total aktiva perusahaan i pada tahun t-1
$\mathrm{PPE}_{\mathrm{i}, \mathrm{t}} \quad$ : Aktiva dan peralatan perusahaan i pada tahun $\mathrm{t}$

$\mathrm{INT}_{\mathrm{i}, \mathrm{t}} \quad$ : Aktiva tidak berwujud perusahaan i pada tahun $\mathrm{t}$

: Laba bersih perusahaan i pada tahun $\mathrm{t}$ 


\section{Variabel Kontrol atau Kendali}

Variabel kontrol adalah variabel yang diupayakan untuk dinetralisasi oleh peneliti. Variabel ini yang menyebabkan hubungan di antara variabel bebas dan variabel terikat bisa tetap konstan. Variabel kontrol merupakan variabel pembanding terhadap variabel yang tengah diuji. Variabel kontrol adalah variabel yang dikendalikan atau dibuat konstan sehingga hubungan variabel bebas terhadap variabel terikat tidak terpengaruhi oleh faktor luar yang tidak diteliti. Variabel kontrol ini digunakan karena peneliti akan melakukan penelitian yang bersifat membandingkan. Variabel kontrol dalam penelitian adalah kategori indeks (syari' $a h=0$ dan konvensional $=1)$.

\section{Metode Analisis Data}

Untuk menganalisis pengaruh corporate governance (komite audit, proporsi dewan komisaris independen, konsentrasi kepemilikan, dan investor institusional) terhadap manajemen laba long term menggunakan alat analisis regresi linear berganda. Namun sebelumnya dilakukan pengujian asumsi klasik, meliputi: uji normalitas, uji multikolinearitas, uji heteroskedastisitas, dan uji autokorelasi. Adapun fungsi persamaan regresi linier berganda diformulasikan sebagai berikut:

$$
\mathrm{Y}=\alpha+\beta_{1} D_{+} \beta_{2} \mathrm{KA}+\beta_{3} \mathrm{DKI}+\beta_{4} \mathrm{KK}+\beta_{5} \mathrm{II}
$$$$
+\mathrm{e}
$$

Keterangan:

$\begin{array}{ll}\mathrm{Y} & : \text { Manajemen Laba } \\ \alpha & : \text { Konstanta } \\ \beta_{1,} \beta_{2,} \beta_{3} & : \text { Koefisien Regresi } \\ \mathrm{D} & : \text { Kelompok Indeks } \\ \mathrm{KA} & : \text { Komite Audit } \\ \mathrm{DKI} & : \text { Dewan Komisaris Independen } \\ \mathrm{KK} & : \text { Konsentrasi Kepemilikan } \\ \mathrm{II} & : \text { Investor Institusional } \\ \mathrm{e} & : \text { Eror }\end{array}$

\section{Hasil dan Pembahasan}

Data penelitian berupa perusahaan yang terdaftar di Bursa Efek Indonesia selam kurun waktu 2011 - 2015 dan tergabung dalam indeks syariah (JII) dan indek konvensional (LQ45). Sampel penelitian berjumlah 226 perusahaan yang diambil secara purposive sampling, dengan rincian dan kriteria sebagai berikut:

Tabel 1. Jumlah Sampel Penelitian

\begin{tabular}{lc}
\hline \multicolumn{1}{c}{ Keterangan } & Jumlah \\
\hline & 375 \\
Populasi perusahaan indeks LQ45 dan JII selama 2011 - 2015 & \\
Perusahaan tidak mempublikasikan laporan keuangan secara berturut-turut se- & $(79)$ \\
lama 2011 - 2015 & $(28)$ \\
Perusahaan yang membuat laporan keuangan tetapi tidak lengkap & 268 \\
Perusahaan yang membuat laporan keuangan secara lengkap & $(42)$ \\
Data outlier & 226 \\
Total sampel & \\
\hline
\end{tabular}

Sumber: data yang diolah.

\section{Uji Asumsi Klasik}

\section{a. Uji Normalitas}

Untuk melihat normalitas sebaran data digunakan uji normalitas. Berdasarkan hasil uji statistik nonparametik Kolmogorov-Smirnov (KS) melalui computer dengan alat bantu program SPSS versi
20.00 diperoleh nilai probalitas sebesar 0,947 (terlampir). Hal ini mengindikasikan bahwa data dalam penelitian berdistribusi normal.

b. Uji Multikolinearitas

Berdasarkan hasil uji Multikolinearitas bahwa semua variabel independen memiliki 
bilai tolerance lebih besar dari 0,10 dan nilai VIF kurang dari 10, berarti datanya terbebas dari
Multikolinieritas. Untuk lebih jelasnya dapat dilihat pada tabel berikut:

Tabel 2. Uji Multikolonieritas

\begin{tabular}{lccl}
\hline \multicolumn{1}{c}{ Model } & Tolerance & VIF & Keterangan \\
\hline Kom_Audit & 0,958 & 1,043 & Bebas multikoleniaritas \\
Dwn_Kom & 0,941 & 1,062 & Bebas multikoleniaritas \\
Kons_Kep & 0,994 & 1,006 & Bebas multikoleniaritas \\
Investor Institusi & 0,971 & 1,030 & Bebas multikoleniaritas \\
\hline
\end{tabular}

Sumber: data yang diolah.

c. Uji Heterokedastisitas

Untuk mengetahui apakah data yang digunakan dalam penelitian ini terjadi heteroskedastisitas ataukah tidak, maka perlu dideteksi dengan menggunakan uji Glejser, apabila nilai signifikansi lebih besar dari 0,05 berarti tidak terjadi gejala heterokedastisitas. Tabel berikut adalah hasil uji dengan menggunakan alat program SPSS versi 20.00 .

Tabel 3. Uji Heterokedastisitas

\begin{tabular}{lccl}
\hline \multicolumn{1}{c}{ Model } & t & Sig. & \multicolumn{1}{c}{ Simpulan } \\
\hline Kom.Audit & $-0,988$ & 0,324 & Bebas Heteroskedastisitas \\
Dwn Kom & $-1,092$ & 0,276 & Bebas Heteroskedastisitas \\
Kons_Kep & $-0,965$ & 0,335 & Bebas Heteroskedastisitas \\
Investor Institusi & 1,201 & 0,231 & Bebas Heteroskedastisitas \\
\hline
\end{tabular}

Sumber: Data yang diolah.

Dari hasil uji heterokedastisitas seperti pada tabel diatas bahwa semua variabel memiliki nilai signifikansi lebih besar dari 0,05 maka dapat disimpulkan bahwa model penelitian tidak mengalami heterokedastisitas.

a. Uji Autokorelasi

Uji ini digunakan untuk menguji apakah dalam suatu model regresi linear ada korelasi antar kesalahan pengganggu (residual) pada periode $\mathrm{t}$ dengan kesalahan pada periode $\mathrm{t}-1$. Berdasarkan hasil dari pengolahan data diperoleh nilai Durbin-Watson sebesar 1,949. Karena nilai ini berada diantara 1,5 sampai 2,5 berarti tidak terjadi gejala autokorelasi.

\section{Analisis Linier Berganda}

Untuk mengetahui pengaruh variabel independen (komite audit, ukuran dewan komisaris, konsentrasi kepemilikan, dan investor isntitusional) terhadap variabel dependen (manajemen laba long term) digunakan alat analisis regresi linear berganda. Penelitian ini menguji seberapa besar pengaruh $(\mathrm{X})$ terhadap $(\mathrm{Y})$. 
Tabel 4. Uji Regresi Linier Beganda

\begin{tabular}{|c|c|c|c|}
\hline Variabel & Koefisien & $\mathbf{t}_{\text {hitung }}$ & Sig \\
\hline (Constant) & $-0,079$ & $-1,138$ & 0,256 \\
\hline Index & 0,579 & 30,747 & 0,000 \\
\hline Kom_Audit & 0,004 & 0,362 & 0,718 \\
\hline Dwn_Kom & $-0,070$ & $-0,956$ & 0,340 \\
\hline Kons_Kep & 0,230 & 4,334 & 0,000 \\
\hline Investor Institusi & 0,012 & 0,192 & 0,848 \\
\hline $\mathrm{R}$ & 0,903 & $\mathrm{~F}$ & 194,827 \\
\hline $\mathrm{R}^{2}$ & 0,816 & Sig & 0,000 \\
\hline Adj. $\mathrm{R}^{2}$ & 0,812 & & \\
\hline
\end{tabular}

Sumber: data yang diolah

Dari hasil olah data diperoleh persamaan sebagai berikut:

$\mathrm{ML}=-0,079+0,579 \mathrm{D}+0,004 \mathrm{KA}+0,070$

$\mathrm{DKI}+0,230 \mathrm{KK}+0,012 \mathrm{II}+\mathrm{e}$

Dari fungsi persamaan regresi berganda di atas dapat diinterprestasikan sebagai berikut:

a. Nilai konstanta sebesar -0,079. Ini berarti bahwa jika semua variabel independent konstan, maka nilai manajemen laba sebesar $-0,079$.

b. Nilai koefisien regresi variabel kelompok indeks sebesar 0,579 ini berarti bahwa kelompok indeks LQ-45 cenderung lebih melakukan manajemen laba dibanding kelompok indeks JII.

c. Nilai koefisien regresi variabel komite audit sebesar 0,004. Hal ini berarti setiap ada penambahan nilai variabel komite audit, maka akan meningkatkan nilai manajemen laba sebesar 0,004 .

d. Nilai koefisien regresi variabel proporsi dewan komisaris independen sebesar $-0,070$. Berarti setiap ada penambahan nilai variabel proporsi dewan komisaris independen, maka akan menurunkan nilai manajemen laba sebesar 0,070 .

e. Nilai koefisien regresi variabel konsentrasi kepemilikan bernilai sebesar 0,230. Ini berarti setiap ada penambahan nilai variabel konsentrasi kepemilikan, maka akan meningkatkan nilai manajemen laba sebesar 0,230.

f. Nilai koefisien regresi variabel investor institusional sebesar 0,012 . Hal ini berarti setiap ada penambahan nilai variabel investor institusional, maka akan meningkatkan nilai manajemen laba sebesar 0,012.

Nilai Adjusted $R^{2}$ sebesar 0,812 atau $81,20 \%$. Berarti variasi perubahan variabel manajemen laba dapat dijelaskan oleh variabel komite audit, proporsi dewan komisaris independen, konsentrasi kepemilikan dan investor institusional, sedangkan sisanya sebesar $18,80 \%$ dijelaskan oleh variabel lain diluar model.

Dari hasil analisis regresi diperoleh nilai $F_{\text {hitung }}$ sebesar 194,827 (lebih besar dari nilai $\left.\mathrm{F}_{\text {tabel }}\right)$ dengan tingkat signifikan 0,000. Karena nilai signifikansi kurang dari nilai alpha 0,05 berarti model yang digunakan dalam penelitian ini adalah tepat atau fit atau robust.

\section{Pengaruh Komite Audit terhadap Manajemen Laba}

Dari hasil pengujian secara parsial (tabel 4), variabel komite audit memiliki nilai $\mathrm{t}_{\text {hitung }}$ sebesar 0,362 dengan nilai signifikansi 0,718 . Berarti komite audit tidak berpengaruh terhadap manajemen laba. Ini terjadi karena 
di Indonesia terdapat peraturan Bapepam yang bersifat mandatory, sehingga tujuan perusahaan membentuk komite audit utamanya hanya sekedar untuk memenuhi ketentuan yang berlaku agar terhindar dari sanksi hukum. Oleh sebab itu, kinerja dari komite audit menjadi tidak efektif dan tidak optimal dalam mengembangkan dan menerapkan proses pengawasan untuk meminimalisir praktik manajemen laba. Bahkan lebih dipertegas lagi oleh Effendi (2009:34), bahwa keberadaan komite audit di perusahaan publik sampai saat ini masih sekedar untuk memenuhi ketentuan pihak regulator (pemerintah) saja. Maka penunjukkan anggota komite audit di perusahaan publik yang sebagian besar bukan didasarkan atas kompetensi dan kapabilitas yang memadai, namun lebih didasarkan pada kedekatan dengan dewan komisaris perusahaan. Anggota komite audit semacam ini sulit diharapkan untuk dapat bekerja secara profesional, sehingga besar kecilnya jumlah komite audit di perusahaan tidak mampu mengurangi terjadinya praktik manajemen laba.

Hasil penelitian ini tidak konsisten dengan penelitian Meiryani (2015); Xie, Wallace dan Peter (2003) yang menyatakan bahwa komite audit berpengaruh terhadap manajemen laba. Dimana semakin banyak anggota komite audit, maka semakin beragam pula keahlian dan pengetahuan dimiliki oleh masing masing anggota sehingga bisa dimanfaatkan untuk mengembangkan dan menerapkan proses pengawasan secara lebih efektif.

\section{Pengaruh Proporsi Dewan Komisaris Independen terhadap Manajemen Laba}

Menurut tabel 4 bahwa proporsi dewan komisaris independen memiliki nilai $t_{\text {hitung }}$ sebesar -0,956 dengan nilai signifikansi sebesar 0,340. Berarti proporsi dewan komisaris independen tidak berpengaruh terhadap manajemen laba. Hal ini disebabkan dewan komisaris independen ditunjuk oleh para pemegang saham mayoritas dalam RUPS. Sehingga jika mereka tidak sejalan dengan keputusan pemilik, maka pemilik dapat melakukan penggantian. Jadi, meskipun komposisi dewan komisaris independen pada perusahaan relatif besar, tetapi mereka tidak bisa benar-benar independen dalam melaksanakan tugas dan pengawasannya. Karena mereka dibatasi oleh kebijakan pemegang saham mayoritas, akibatnya mereka tidak mampu menjalankan fungsinya untuk mengurangi praktik manajemen laba.

Di sisi lain semakin banyak jumlah dewan komisaris independen semakin menimbulkan masalah keagenan. Sebab semakin banyak anggota dewan komisaris independen, perusahaan semakin mengalami kesulitan dalam berkomunikasi dan mengkoordinir kerja dari masing-masing anggota dewan itu sendiri, kesulitan dalam mengawasi dan mengendalikan tindakan manajer, dan kesulitan dalam mengambil keputusan yang bermanfaat bagi perusahaan. Berbagai kesulitan tersebut dapat berdampak pada penurunan kinerja perusahaan.

Hasil penelitian ini konsisten dengan penelitian Susanto (2016) yang menyatakan bahwa banyak sedikitnya dewan komisaris independen tidak mampu mengendalikan pihak manajemen untuk mengurangi praktik manajemen laba. Memang banyak sedikitnya dewan komisaris independen bukan sebagai faktor penentu utama dari efektivitas pengendalian terhadap manajemen perusahaan. Tetapi efektivitas pengendalian lebih tergantung pada nilai, norma dan kepercayaan yang diterima oleh suatu perusahaan, serta peran dewan komisaris dalam aktivitas pengendalian (monitoring) terhadap manajemen (Jennings, 2005).

Menurut Effendi (2009:20) dalam kaitannya dengan implementasi good corporate governance (GCG) di perusahaan diharapkan bahwa keberadaan dewan komisaris termasuk komisaris independen tidak hanya sebagai pelengkap, tetapi dalam diri komisaris juga melekat tanggung jawab secara hukum. Namun dalam praktik yang terjadi di Indonesia terdapat kecenderungan bahwa kedudukan direksi biasanya sangat 
kuat, bahkan ada direksi yang enggan membagi wewenang serta tidak memberikan informasi yang memadai kepada komisaris independen.

Selain itu juga ada kendala yang cukup menghambat kinerja komisaris independen yaitu masih lemahnya kompetensi dan integritas mereka. Ini terjadi karena pengangkatan komisaris biasanya harus didasarkan pada penghargaan, hubungan keluarga, atau hubungan dekat lainnya. Padahal integritas dan independensi merupakan sesuatu yang fundamental agar GCG dalam perusahaan dapat terwujud secara efektif. Oleh karena itu, dewan komisaris independen di perusahaan masih belum bisa bekerja secara efektif dalam meningkatkan pengawasan terhadap operasional perusahaan dan terbukti tidak mampu mengurangi praktik manajemen laba.

\section{Pengaruh Konsentrasi Kepemilikan terhadap Manajemen Laba}

Dari hasil pengujian secara parsial pada tabel 4, variabel kepemilikan konsentrasi memperoleh nilai $t_{\text {hitung }}$ sebesar 4,334 dengan nillai signifikan sebesar $0,00 . \mathrm{MakaH}_{3}$ diterima, berarti konsentrasi kepemilikan berpengaruh positif terhadap manajemen laba. Hasil penelitian ini konsisten dengan Alves (2012) menunjukkan bahwa konsentrasi kepemilikan berpengaruh terhadap manajemen laba. Hal ini menunjukkan bahwa semakin tinggi konsentrasi kepemilikan maka semakin tinggi pula praktik manajemen laba yang dilakukan oleh perusahaan. Namun tidak sejalan dengan penelitian Kamran dan Attaullah (2014) yang menjelaskan bahwa konsentrasi kepemilikan berpengaruh negatif terhadap manajemen laba.

Konsentrasi kepemilikan perusahaan yang terdaftar dalam indeks syariah lebih memfokuskan pada current earning, akibatnya manajer terpaksa untuk melakukan tindakan yang dapat meningkatkan laba dalam jangka pendek melalui praktik manajemen laba. Konsentrasi kepemilikan akan membuat manajer merasa terikat untuk memenuhi target laba dari investor, sehingga mereka akan cenderung terlibat dalam tindakan memanipulasi laba. Konsentrasi kepemilikan menjadikan pemilik bisa bertindak sesuai kepentingan dirinya sendiri. Pemilik mayoritas bisa menjadi bagian dari jajaran manajemen atau bahkan menempatkan orangnya menjadi manajer itu sendiri. Konsentrasi kepemilikan yang memasukkan orang-orangnya kedalam jajaran manajemen perusahaan dapat melakukan rekayasa laba yang menguntungkan pemegang saham mayoritas dan manajemen tetapi merugikan pemegang saham minoritas.

\section{Pengaruh Investor Institusi terhadap Manajemen Laba}

Dari hasil pengujian secara parsial pada tabel 4 menunjukkan bahwa variabel investor institusi memperoleh nilai $t_{\text {hitung }}$ sebesar 0,192 dengan nilai signifikan 0,848. Berarti $\mathrm{H}_{4}$ ditolak investor institusi tidak berpengaruh terhadap manajemen laba. Hasil penelitian ini konsisten dengan Hsu and Shiow (2015), namun tidak sejalan dengan penelitian Kamran dan Attaullah (2014) yang menjelaskan bahwa Investor Institusi berpengaruh terhadap manajemen laba.

Besarnya kepemilikan saham dalam perusahaan tidak merubah perilaku manajemen dalam melakukan praktik manajemen laba. Hal ini menunjukkan ketidakmampuan investor institusi untuk mengendalikan pihak manajemen melalui proses monitoring. Sehingga proses pengawasan yang dilakukan menjadi kurang efektif, dan tidak mampu mengurangi praktik manajemen laba yang dilakukan oleh manajemen perusahaan (Hidayanti dan Paramita, 2014).

Investor institusi lebih mementingkan kinerja perusahaan jangka panjang, oleh sebab itu manajer tidak memiliki dorongan untuk melakukan manajemen laba sekarang (Wedari, 2004). Selain itu, investor institusi merupakan investor yang dianggap sebagai pemilik sementara yang lebih memfokuskan pada laba sekarang sehingga dapat mempengaruhi pengambilan keputusan (Effendi dan 
Daljono, 2013). Banyak sedikitnya hak suara yang dimiliki oleh institusi tidak dapat mempengaruhi tingkat besar kecilnya praktik manajemen laba yang dilakukan manajemen (Tiswiyanti et al., 2012).

\section{Simpulan}

1. Perusahaan yang tergabung dalam indeks konvensional (LQ-45) cenderung lebih banyak melakukan praktik manajemen laba dibanding dengan perusahaan yang tergabung dalam indeks syari'ah (JII).

2. Komite audit tidak berpengaruh terhadap manajemen laba, sehingga hipotesis pertama tidak terbukti kebenarannya.

3. Proporsi dewan komisaris independen tidak berpengaruh terhadap manajemen laba, berarti hipotesis kedua tidak terbukti kebenarannya.

4. Konsentrasi kepemilikan berpengaruh positif terhadap manajemen laba. Berarti hipotesis ketiga terbukti kebenarannya.

5. Investor Institusi tidak berpengaruh terhadap manajemen laba, berarti hipotesis keempat tidak terbukti kebenarannya.

6. Dalam mengukur manajemen laba peneliti menggunakan pendekatan long term discretionary accrual, maka penelitian mendatang perlu menggunakan pendekatan lain.
7. Corporate governance internal hanya diproksi dengan komite audit dan dewan komisaris, sedangkan corporate governance eksternal hanya diproksi dengan konsentrasi kepemilikan dan investor institusi. Maka penelitian mendatang perlu menambah variabel dewan direksi dan audit internal untuk corporate governance internal dan menambah variable kepemilikan pemerintah untuk corporate governance eksternal.

8. Data yang dianalisis hanya selama periode pengamatan 2011 - 2015, maka agar mendapatkan hasil yang lebih lebih baik penelitian mendatang perlu menambah periode pengamatan hingga tahun 2018.

\section{Persantunan}

1. Penelitian ini dibiayai oleh Direktorat Riset dan Pengabdian Masyarakat Direktorat Jenderal Penguatan Riset dan Pengembangan Kementrian Riset, Teknologi, dan Pendidikan Tinggi Sesuai dengan Kontrak Penelitian No. : 211.60/A.3-III/LPPM/V/2017.

2. Ucapan terima kasih disampaikan kepada seluruh anggota tim Penelitian ini (Dr. Noer Sasongko; Dra. Rina Trisnawati, M.Si, Ak., Ph.D; Ecclisia Sulistyowati; Nur Ismiyati Fauziah; dan Dwi Cahyani)

\section{Daftar Pustaka}

Alves, Sandra. 2012. "Ownership Structure and Earnings Management: Evidence from Portugal”. Journal Accounting Business and Finance. Vol. 6 No.1. pp. 57-74.

Chtourou, Sonda Marrakchi, Jean Bedard, dan Lucie Courteau. (2001). Corporate Governance and Earnings Management. Workingpaper, April.

Dechow, Patricia M., R.G. Sloan Hal, A.P. Sweeney. (1996). Causes And Consequences Of Earnings Manipulaton: An Analysis Of Firms Subject To Enforcement Actions By The SEC. Contemporary Accounting Research 13, 1-36

Effendi, Arief. (2009). "The Power of Good Corporate Governance Teori dan Implementasi”. Jakarta: Salemba Empat.

Effendi, Sofyan \& Daljono. 2013. Pengaruh Corporate Governance dan Kualitas Auditor Terhadap Manajemen Laba dalam Diponegoro Journal of Accounting ISSN: 2337-3806 Vol. 2 No. 3. 
Gulzar, M. A., Wang, Z. (2011). Corporate Governance Characteristics and Earnings Management: Empirical Evidence from Chinese Listed Firms, International Journal of Accounting and Financial Reporting, 1(1), 2162-3082.

Hermawan, Ancela. A. 2011. "The Influence Of Effective Board Of Commissioners and Audit Committee On The Informativeness Of Earning: Evidence From Indonesian Listed Firm". Asia Pacific Journal Of Accounting and Finance. Vol. 2, No. 1, pp. 1-38.

Hidayanti, Ery Dan Ratna Widjayanti Dahniar Paramita .2014. Pengaruh Good Corporate Governance Terhadap Praktik Manajemen Laba Riil Pada Perusahaan Manufaktur. Jurnal Wiga Issn No 2088-0944 Vol. 4 No. 2, September 2014.

Hsu, Ming-Feng, and Shiow-Ying, W. 2015. "The Roles of Institutional Investors and Insiders in Earnings Management around Initial Public Offering Firms in Taiwan". Journal of Economicd and Financial Issue. Vol. 5 No.2. pp. 340-353.

Iqbal, Syaiful dan Nurul Fachriyah. (2008). Corporate Governance sebagai Alat Pereda Praktik Manajemen Laba (Earnings Management). Jurnal Perbanas, Vol. 12 No. 3.

Jalil, Azina. A. and Rashidch, A.R. 2010. "Institutional Investor and Earning Management Malaysian Evidence”. Journal of Financial Reporting and Acounting. Vol. 8 No. 2, pp 110-127.

Jennings, M.M. 2005. "Conspicuous Governance Failures: Why Sarbanes-Oxley Is Not An Ethics Warranty”. Corporate Finance Review Vol. 9 No. 5, p. 41-47.

Juliardi, Dodik. 2013. "Pengaruh Laverage, Konsentrasi Kepemilikan dan Kualitas Audit Terhadap Nilai Perusahaan Serta Laba Peristen Pada Perusahaan-perusahaan Publik Manufaktur yang Listed di Bursa Efek Indonesia". Jurnal Akuntansi Aktual. Vol. 2 No.2. pp. 112-122.

Kamran, Attaullah. S. 2014. "The Impact of Corporate Governance and Ownership Structure on Earnings Management Practices: Evidence from Listed Companies in Pakistan". Journal Of Economics. Vol. 19 No. 2. pp. 27-70.

Klein, A. 2002. Audit Committee, Board of Directors Characteristics and earnings Management. Journal of Accounting and Economics 33, Hal. 375-400.

Kusuma, Indra. 2012. Pengaruh Corporate Governance, "Struktur Kepemilikan, dan Ukuran Perusahaan Terhadap Manajemen Laba". Jurnal Akuntansi dan Sistem Teknologi Informasi . Vol. 9, No. 1, hal. 41-54.

Kusuma, H. (2006). Dampak Manajemen Laba terhadap Relevansi Informasi Akuntansi: Bukti Empiris dari Indonesia. Jurnal Akuntansi dan Keuangan, 1-12.

Meiryani. 2015. "Mechanism Of Good Corporate Govermance, Earning Management of Financial Performance in Bank Listed in Indonesia Stock Exchange Using Path Analysis". Australian Journal Of Basic and Applied Scienies. Vol. 9, pp. 573-584.

Miko, Nuradden. U and Hasnah. K. 2015. "Impact of Audit Committee and Audit Quality on Preventing Earnings Management in the Pre- and Post- Nigerian Corporate Governance Code 2011". Social and Behavioral Sciences. Vol. 172, pp. 651-657.

Nasution, Marihot dan Doddy Setiawan. 2007. "Pengaruh Corporate Governance terhadap Manajemen Laba di Industri Perbankan Indonesia". Disampaikan pada Simposium 
Nasional Akuntansi X Makassar.

Nisfiannoor, Muhammad. 2009.'Pendekatan Statistika Modern Untuk Ilmu Sosial”. jakarta: Salemba empat

Nuryaman. 2009. "Pengaruh Konsentrasi Kepemilikan, Ukuran Perusahaan dan Mekanisme Corporate Governance Terhadap Pengungkapan Sukarela". Jurnal Akuntansi dan Keuangan Indonesia. Vol. 6 No. 1, hal 89-116.

Peasnell K, Pope P, Young S. (2001). Board Monitoring and Earnings Management: Do Outside Directors Influence Abnormal Accruals? Working Paper, Lancaster Univerisity, Lancaster, U.K.

Pratana Puspa Midiastuty dan Mas'ud Mahfoedz. (2003). Analisis Hubungan Mekanisme Corporate Governance dan Indikasi Manajemen Laba. Seminar Nasional Akuntansi VI. Hal. 176-199. Surabaya.

Qiesari, Rouh. A. and Mohammad, R.A. 2016. "The Relationship Between Corporate Governance and Firm Value in Companies Listed on Tehran Stock Exchange (TSE)". IIOABJ . Vol. 7 No. 1, pp. 101-106.

Rachman, Gun, G. 2014. "The Effect Of Board Of Commisioners, Audit Committee, and Internal Auditor On Financial Reporting Quality Of Banks Listed On The Indonesia Stock Exchange". Journal Of Economics, Commerce and Management. Vol. 2 No. 10. pp. 1-27

Rahman, Abdul Rashidah, dan Fairuzana Haneem Mohammed Ali. (2006). Board, Audit Committee, Culture And Earnings Management: Malaysian Evidence Managerial Auditing Journal 21 (7): 783 - 804

Roodposhti, F. R., \& Chasmi, S. A. (2011). Impact of Corporate Governance Mechanism on Earnings Management. African Journal of Business Management, 5(11), 4143-4151.

Scott, William R. 2006. Financial Accounting Theory 4th Edition. United State of America : Pearson Prentice Hall.

Siregar, Sylvia Veronica N.P., dan Siddharta Utama. 2005. “Pengaruh Struktur Kepemilikan, Ukuran Perusahaan, dan Praktik Corporate Governance Terhadap Pengelolaan Laba (Earning Manajement)". Disampaikan pada Simposium Nasional Akuntansi VIII Solo.

Sulistyanto, Sri H. 2008. Manajemen Laba: Teori dan Model Empiris. Jakarta: Grasindo.

Susanto, Y. K., and Pradipta, A. 2016. "Corporate Governance and Real Earning Management". International Business, Economic and Law. Vol. 9 No. 1. pp. 17-23.

Tarjo. (2008). Pengaruh Konsentrasi Kepemilikan Institusional dan Leverage terhadap Manajemen Laba, Nilai Pemegang Saham serta Cost of Equity Capital. Simposium Nasional Akuntansi XI

Trisnawati, Rina.,Wiyadi.,Noer S. (2012, April). "Pengukuran Manajemen Laba: Pendekatan Terintegrasi”. Riset Ilmiah. Hal 1-40.

Trisnawati, Rina. 2009. "Perbedaan Mekanisme Corporate Governance dan Praktik Manajemen Laba: Studi Komparasi Indeks Syariah dan Indeks Konvensional di Bursa Efek Indonesia”. UNISIA. Vol. 32 No. 72. hal. 129-142.

Trisnawati, R., Erma., Wiyadi., Zulfikar. 2016. "Pengaruh Corporate Governance terhadap Hubungan Pengungkapan Corporate Social Responbility dengan Cost OfEquity Capital”. 
Riset Ilmiah. Hal 132-144.

Trisnawati, Rina., and Sidiq, P.N. 2011. "Earning Management Practices: The Comparative Studies Between Shariah Index (JII) and Conventional Index (LQ45) In Indonesian Stock Exchange". Paper is part of Hibah Pasca-I research that is funded by DP2M, Dirjen Dikti. Pp. 1272-1282.

Tiswiyanti, Wiwik, Dewi Fitriyani dan Wiralestari. 2012. "Analisis Pengaruh Komisaris Independen, Komite Audit, dan Kepemilikan Institusional terhadap Manajemen Laba". Jurnal Penelitian Universitas Jambi Seri Humaniora, Vol.14, No.1, Hal. 61-66 Januari Juni 2012.

Ujiyanto dan Bambang A. Pramuka (2007), Mekanisme Corporate Governance, Manajemen Laba Dan Kinerja Keuangan ( Studi Pada Perusahaan go publik Sektor Manufaktur ), Simposium Nasional Akuntansi X, Unhas Makasar 26-28 Juli 2007.

Wedari, Linda Kusumaning. (2004). Analisis Pengaruh Proporsi Dewan Komisaris dan Keberadaan Komite Audit terhadap Aktivitas Manajamen Laba. Simposium Nasional Akuntansi 7.

Whelan, C., \& McNamara, R. (2004). "The Impact of Earnings Management on the Value Relevance of Financial Statement Information”. Paper available from http://paper.ssrn. com download on 15 Mei 2017.

Wiyadi., Rina, T., Noer, S. 2013. "Implementation Of Corporate Governance Mechanism and Earning Management On Jakarta Index (JII) and LQ45 Index”. Riset Ilmiah. pp. 1-18.

Wiyadi; Sutanta. (2013). Analysis of Corporate Governance Mechanism and Earnings Management: Short Term and Long Term Accrual Models". Proceeding International Conference The $14^{\text {th }}$. MIICEMA. Bogor.

Xie, B.,Wallace, N. DIII, and Peter, J.D. 2003. "Earnings Management and Corporate Governance: The Role Of The Board and The Audit Committee". Journal of Corporate Finance. Vol. No. 9. pp.295-316 (www.idx.co.id, diakses pada tanggal 6/7/2017) 